\title{
Application of PV Solar System in Statcom to Regulate the Active \& Reactive Power in the Distribution Network
}

\author{
Gunjan A. Patel \\ PG Student at dept. of Electrical Engineering, Parul Institute of Engineering and Technology
}

\begin{abstract}
This project presents the new technique for STATCOM say PV-STATCOM. Means it gives the active and reactive power to the system using PV arrays. For day time as the demanded load is very high so PV-STATCOM will give the active power. For night time the load is little bit at lower side so it is more important to stabilize the system voltage by injecting reactive power to the grid. It means this system will automatically take decision what is the requirement of the grid right now as per the requirement it will deliver power to the grid.
\end{abstract}

Keywords: PV (Photovoltaic) Solar system, STATCOM, MATLAB.

\section{Introduction}

In Recent days, we are mostly dependent on nonconventional sources that have been and will continue to be a major cause of pollution and other environmental degradation. The solar panels only work during day time because unavailability of sunlight at night time. Hence, all of the solar power capacity is lost during night. This could be a problem regarding power quality if the PV panel is connected to the distribution system. Ever increasing demand of electricity necessitates the use of renewable energy at a greater extent. Due to severe hike in global warming, we need to tap maximum amount of renewable energy available in the nature. Solar energy is the largest available renewable energy. We can use PV panels to convert this energy into electrical energy. Here, I try to simulate a PV panel that will work during day and night time. This will use PV as STATCOM also known as PVSTATCOM. This will provide power factor correction and control voltage at the load terminals during night time, and during daylight, the PV-STATCOM will provide real power along with above mentioned characteristics. We could use this PV-STATCOM on the rooftops of the industries that consumes large electrical power. PV-STATCOM helps in mitigating global warming by providing clean energy during day and night.

\section{Configuration of PV (Photovoltaic Penal or Cell)}

The PV cell generates DC electricity whenever it is subjected to sunlight. Solar radiation sustains all forms of life on earth. The sun radiates $1.74 \times 10^{17} \mathrm{~W}$ of power per hour to earth the daily solar energy radiation varies from 4-7 $\mathrm{kWh}$ per and there are 270-300 sunny days in a year. Generated power in the single PV cell is very less. For practical applications many PV cells are interconnected. Number of cells in series decides the voltage and the number of cells in parallel decides the current.

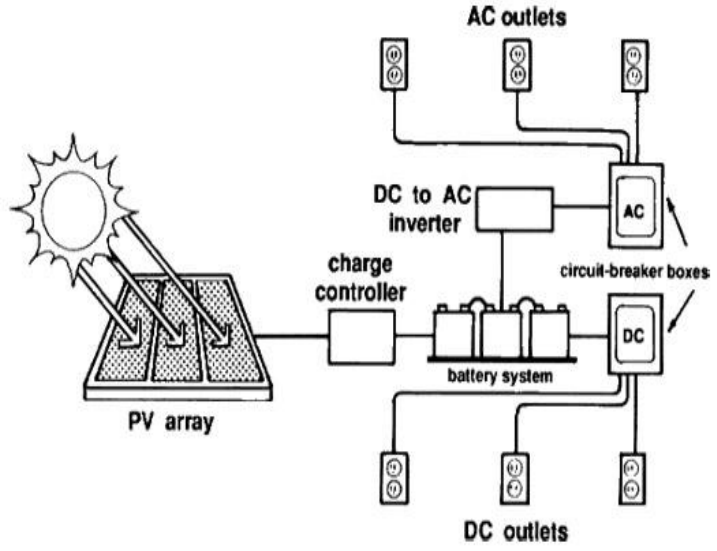

Figure 1: PV effect converts the photon energy into ac \& dc

\section{Control Scheme}

In this Section we will discuss about database used for this dissertation work, performance Parameters, Implementation and results. The Photovoltaic (PV) use to analysis the PV model and then the simulate the PV model in MATLAB. Then output of the PV model is compared with the different temperature \& insolation.

\section{STATCOM}

STATCOM is a shunt FACTS device, which employs power electronics devices likeGate Turn Off, Insulated Gate Bipolar Transistors to regulate the power flow and stability of the electrical power system. STATCOM is the active and reactive power compensator. If we want to give Active Power form STATCOM. Active Power side both of the voltage and current in phase. When injecting current at PCC (Point of common coupling) must be in phase with supply voltage.

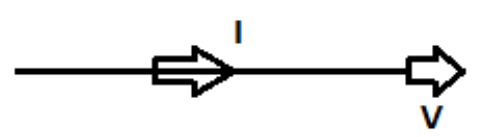

Figure 2: In phase current \& voltage. 


\section{International Journal of Science and Research (IJSR) \\ ISSN (Online): 2319-7064}

Index Copernicus Value (2013): 6.14 | Impact Factor (2015): 6.391

If we want to give Reactive Power form STATCOM. Reactive Power side voltage and Injecting current must be perpendicular from each other. When injecting current form the STATCOM must be 900 shifted from the supply voltage.

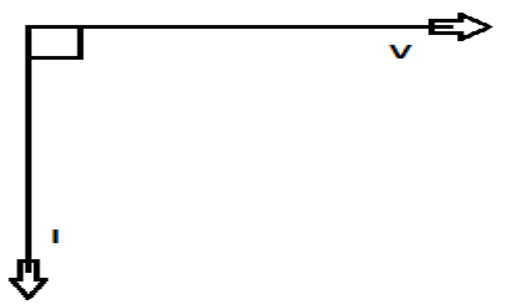

Figure 3: Current \& Voltage $90^{\circ}$ shifted

STATCOM controller gives voltage support by generating $\&$ absorbing reactive power at the PCC without the need of more external reactors or capacitor storage

\section{Simulation for PV}

PV module(penal) is taken as the reference module for simulation data details are given in Table 1 .

Table 1: Electrical characteristics data

\begin{tabular}{|c|c|}
\hline Voltage at Maximum power (Vmp) & $40.1 \mathrm{~V}$ \\
\hline Current at Maximum power ( Imp) & $9.01 \mathrm{~A}$ \\
\hline Short circuit current ( ISCr) & $2.55 \mathrm{~A}$ \\
\hline Total number of cells in series (Ns) & 36 \\
\hline Total number of cells in parallel (Np) & 1 \\
\hline
\end{tabular}
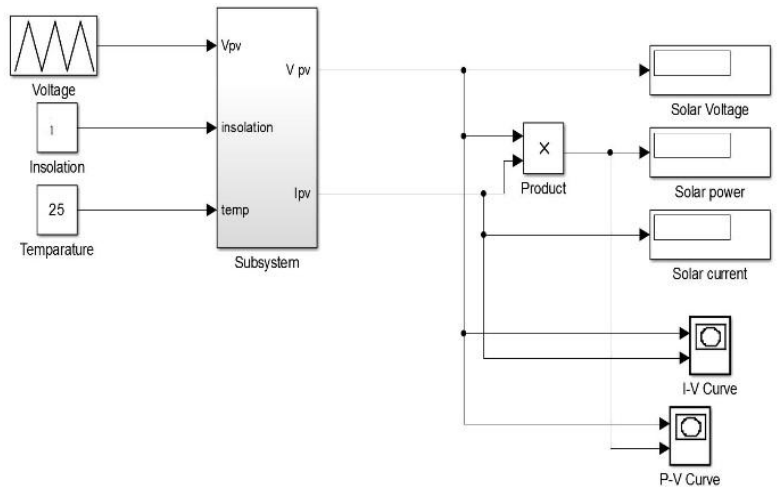

Figure 4: Simulink model of PV module

\section{Simulation Results}

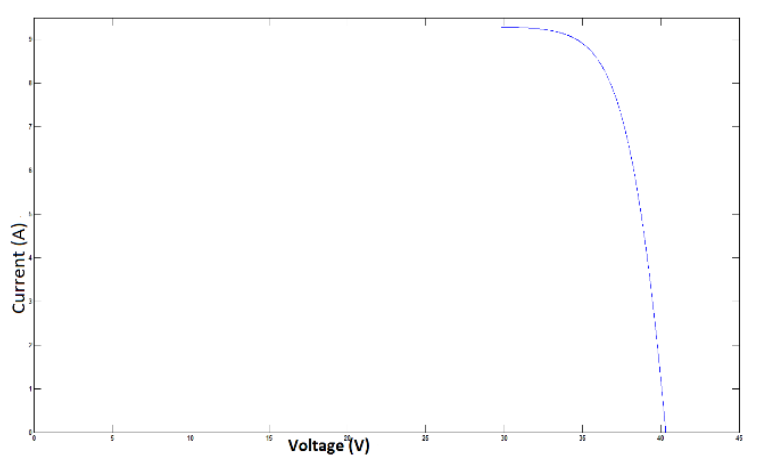

Figure 5: I-V Curve

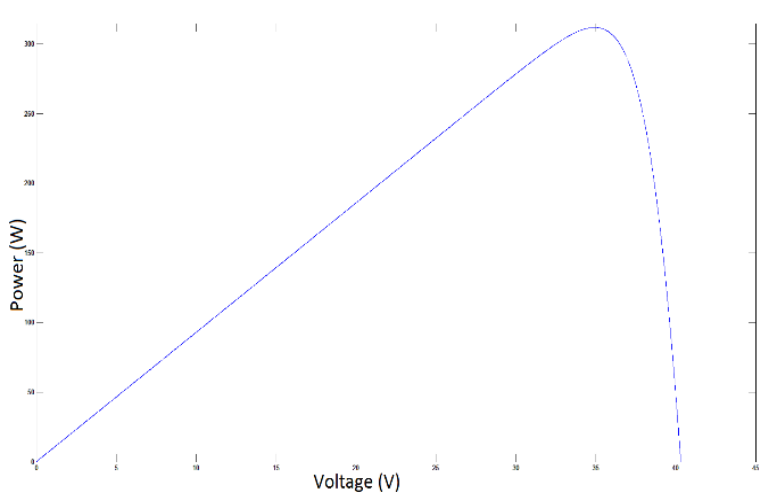

Figure 6: P-V Curve

In $\mathrm{I}-\mathrm{V}$ curve when $\mathrm{I}_{\mathrm{sc}}$ maximum at that time voltage is zero and when $\mathrm{V}_{\mathrm{OC}}$ is maximum at that time current is zero. In IV curve any term current or voltage is zero that's why power will zero. But in case of P-V curve when multiplication of current and voltage we get maximum power at one point is called maximum power point (MPP).

\section{Simulation of complete system}

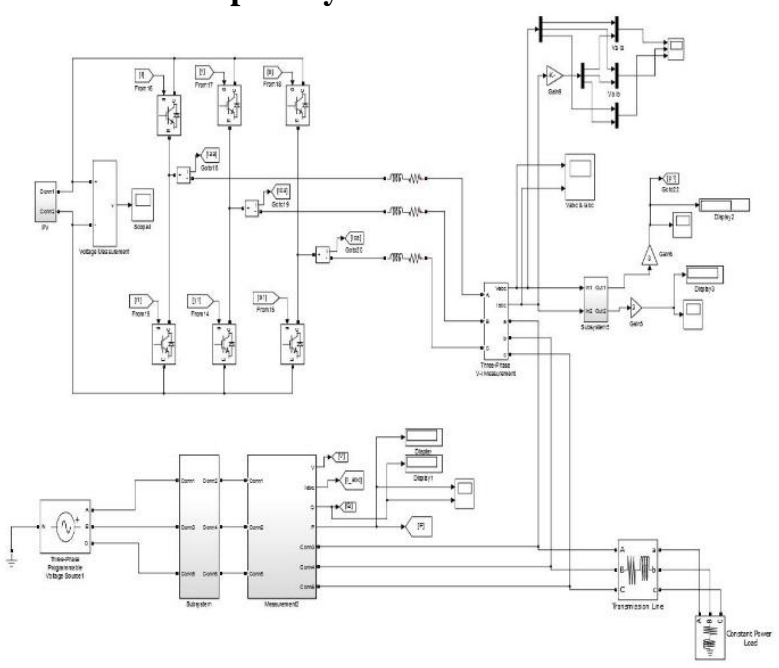

Figure 7: 415 v System for Active \& Reactive Power with PV

415 v Result for Active Power

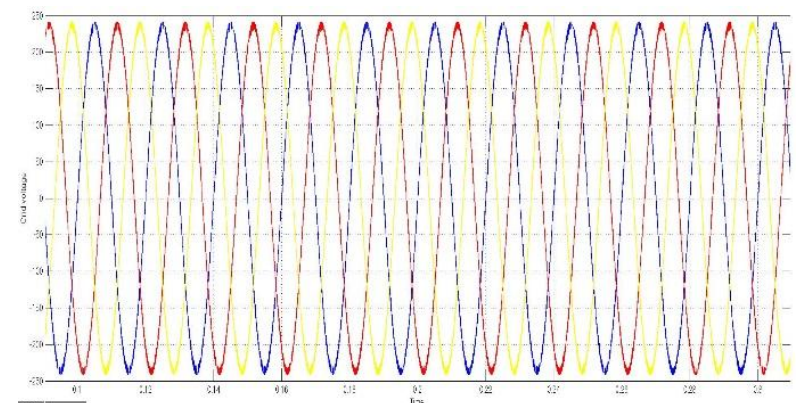

Figure 8: Grid Voltage 


\section{International Journal of Science and Research (IJSR) \\ ISSN (Online): 2319-7064}

Index Copernicus Value (2013): 6.14 | Impact Factor (2015): 6.391

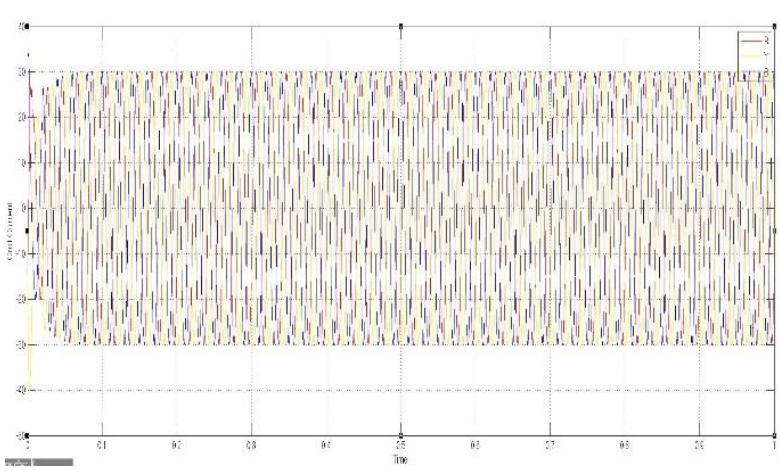

Figure 9: Grid Current

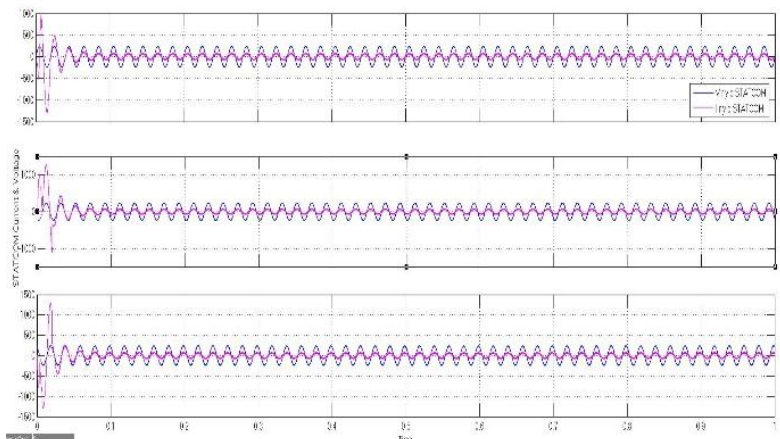

Figure 10: STATCOM Voltage \& Current in Phase

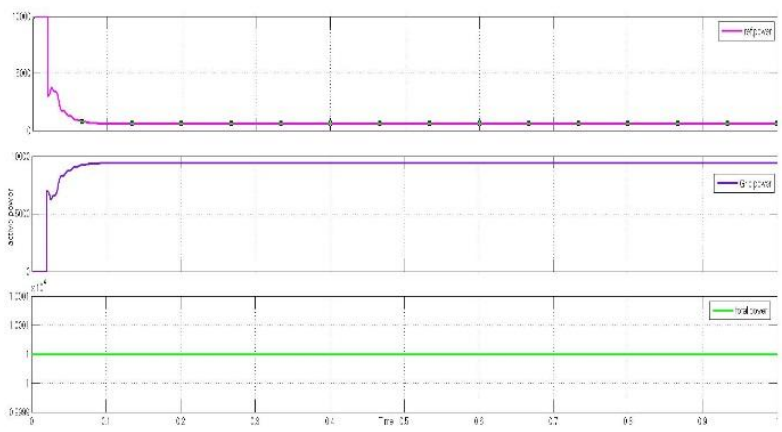

Figure 11: Active Power

\section{5 v Result for Reactive Power}
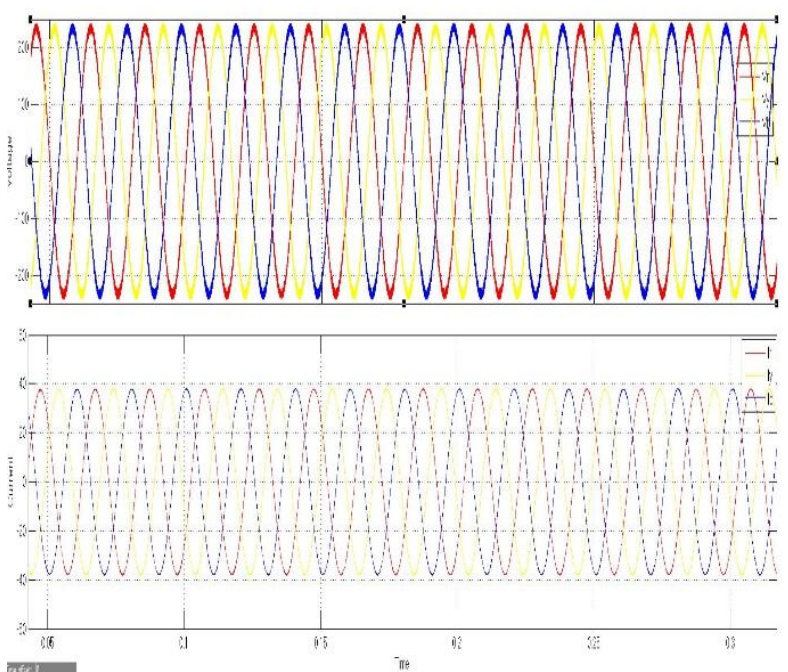

Figure 12: Grid Voltage \& Current

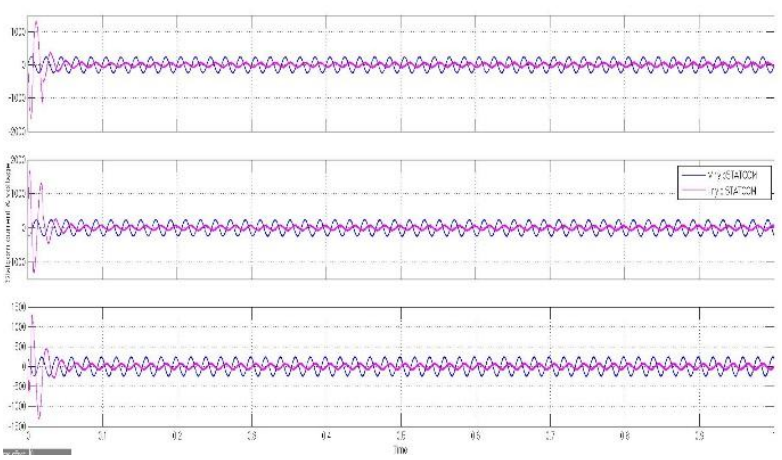

Figure 13: STATCOM Voltage $\&$ Current $90^{\circ}$ apart to each other

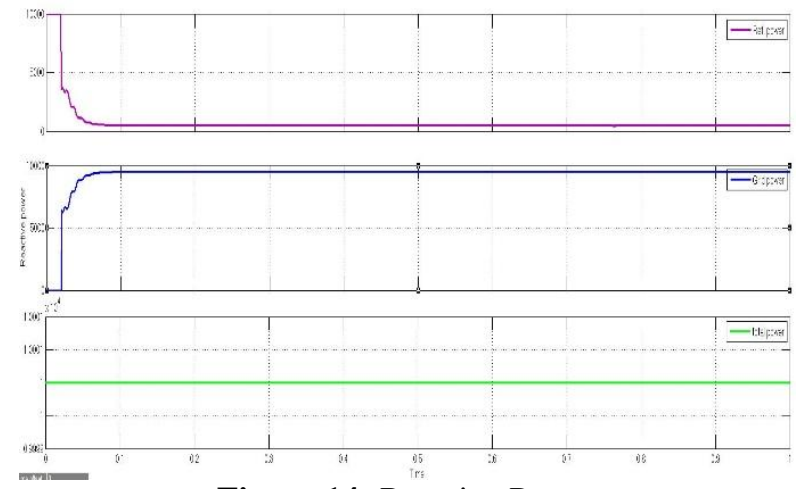

Figure 14: Reactive Power

\section{Conclusion}

The given STATCOM system integrated with the grid can supply the required deficit reactive power into the grid for batter efficiency, power factor as well as stability purpose. In this case STATCOM will inject the current at 90 degree lagging with grid voltage

- As the injected current from the STATCOM is in phase with the grid voltage that we can see from the MATLAB results. It proves that STATCOM can provide only active power to the grid for this simulation work.

- As the injected current from the STATCOM is $90^{\circ}$ phase shift with the grid voltage that we can see from the MATLAB results. It proves that STATCOM can provide only reactive power to the grid for this simulation work.

- For supplying this active/reactive power STATCOM is supplied by the PV system.

\section{References}

[1] Rajiv. K. Varma, Ehsan M. Siavashi, Byomakesh Das, and Vinay Sharma, "Novel application of a PV Solar Plant as STATCOM during Night and Day in a Distribution Utility Network: Part 2", Paper Presented in Panel Session on "FACTS/Power Electronics Installations" 2012 IEEE PES Power Systems Conference \&Expo,May, 7- 10, Orlando, Florida, USA.

[2] Rajiv. K. Varma, Byomakesh Das, IurieAxente, and Tim Vanderheide, "Optimal 24-hr Utilization of a PV Solar System as STATCOM (PVSTATCOM) in a Distribution Network", Proc. IEEE PES GeneralMeeting, Detroit, USA, 2011.

\section{Volume 5 Issue 6, June 2016 www.ijsr.net}




\section{International Journal of Science and Research (IJSR) \\ ISSN (Online): 2319-7064}

Index Copernicus Value (2013): 6.14 | Impact Factor (2015): 6.391

[3] Rajiv. K. Varma, Shriram. S. Rangarajan, IurieAxente, and Vinay Sharma, "Novel application of a PV Solar Plant as STATCOM during Night and Day in a Distribution Utility Network", Paper Presented in Panel Session on "FACTS/Power Electronics Installations" 2011 IEEEPES Power Systems Conference \& Expo, March 20-23, 2011, Phoenix, Arizona, USA.

[4] R. K. Varma and V. Khadkikar, "Utilization of a PV solar farm Inverter as STATCOM," U.S. Patent, Sep. $15,2009$.

[5] R.K. Varma, V. Khadkikar and R. Seethapathy, "Nighttime Application of PV Solar Farm as STATCOM to Regulate Grid Voltage," IEEETranson EnergyConversion (Letters), vol.24, no.4, pp.983-985, Dec.2009.

[6] INTERNATIONAL JOURNAL OF SCIENTIFIC \& TECHNOLOGY RESEARCH VOLUME 3, ISSUE 8, AUGUST 2014 ISSN 2277-8616 33 IJSTR@2014 www.ijstr.org " Utilization Of PV Solar Farm As STATCOM During Night Hours In A Distribution Network" M. SaiEswarRao, K. Obulreddy

[7] M. Sai Eswar Rao, K. Obulreddy, “Utilization Of Pv Solar Farm As Statcom During Night Hours In A Distribution Network", International Journal Of Scientific \& Technology Research Volume 3, Issue 8, August 2014

[8] S., R.K.Nema, and G.Agnihotri, "Matlab / simulink based study of photovoltaic cells / modules / array and their experimental verification," International Journal of Energy and Environment,

[9] M. H. Rashid "Power Electronics Handbook". London, U.K.: Academic (2010)

Volume 5 Issue 6, June 2016 www.ijsr.net 